\title{
Hydrolysis of Milk Fat By Lipase in Solvent-free Phospholipid Reverse Micellar Media
}

\author{
MAYANK T. PATEL, R. NAGARAJAN, and ARUN KILARA
}

\section{ABSTRACT}

Butterfat was hydrolyzed with lipases contained in lecithin reverse micelles. The influence of $\mathrm{pH}$, temperature, molar ratio of surfactant to water $(\mathrm{R})$ and surfactant concentration on the hydrolytic reaction indicated linear, quadratic, and interactive effects for reaction systems mediated by $R$. javanicus and $C$. rugosa lipases. The initial reaction rate was dependent on reaction parameters; however, the degree of hydrolysis was independent of $\mathrm{pH}$. Both enzymes exhibited high thermal stability. The content and composition of milk fat hydrolysates prepared by $R$. javanicus lipase were most influenced by reaction temperature and $\mathrm{R}$. The optimum conditions for production of free fatty acids, monoacylglycerols, diacylglycerols and specific regio-isomers were defined.

Key Words: butterfat, lipase, lecithin, reverse micelles, fat hydrolysates

\section{INTRODUCTION}

CHANGES IN AMERICAN DIETARY HABITS have led to a surplus of milk fat (butter oil). Research that may lead to unique uses of milk fat is needed. A key attribute of milk fat is its unique flavor, which can be increased in use with conversion to functional ingredients using lipolytic enzymes. This aspect of enzyme-modified lipid ingredients was reviewed by Kilara (1985). Conventionally, milk fat has been hydrolyzed by lipases (triacylglycerol acylhydrolase, E.C. 3.1.1.3) in aqueous emulsion systems to yield various types of flavors. Lipase-mediated bioconversion of triacylglycerols (TAG) and other sparingly watersoluble compounds in low aqueous media (such as reverse micelles) is of interest for production of food ingredients (Bello et al., 1987; Holmberg and Osterberg, 1987, 1988; Holmberg et al., 1989; Kim and Chung, 1989; Osterberg et al., 1989; Hayes and Gulari, 1990; Nagao and Kito, 1990). Reverse micellar medium is the micellar solution of a surfactant in organic solvent, where enzyme and water are solubilized in the core of the micelles and water-insoluble substrate is solubilized in the bulk solvent. Lipase reactions in such media have several advantages over reactions in aqueous systems. These include increased reaction rates and yields, increased thermal stability, lower costs and lower reaction volumes. They also have good protection from protection from microbial contamination, product inhibition, and provide reuse of enzyme.

Reverse micellar media comprised of bis(2-ethylhexyl) sodium sulfosuccinate (Aerosol-OT) and iso-octane have been reported (Han and Rhee, 1985; Han et al., 1987, 1990; Chang and Rhee, 1990; Schmidli and Luisi, 1990; Stark et al., 1990) to study hydrolysis of TAG. The hydrolysis of two model substrates (olive and coconut TAG) has also been reported in a novel solvent-free reverse micellar media composed of a purified lecithin as surfactant and substrate TAG as continuous nonpolar medium (Chen and Pai, 1991). The solvent-free lecithin reverse micellar medium is more suitable than the AerosolOT/iso-octane medium for food application because of possible toxicity associated with the organic solvent and the use of syn-

Author Kilara is with the Dept. of Food Science and author $\mathrm{Na}$ garajan is with the Dept. of Chemical Engineering, The Pennsylvania State Univ., University Park, PA 16802. Author Patel's current address: General Mills, James Ford Bell Technical Center, Minneapolis, MN. Address inquiries to Dr. Arun Kilara. thetic surfactant. Further studies on hydrolysis of milk fat in solvent-free reverse micellar media using commercial grade lecithin (soy lecithin) and commercial enzymes were conducted. The objective was to study this system for applications and to identify conditions for converting milk fat to ingredients with multiple functionalities.

\section{MATERIALS \& METHODS}

\section{Materials}

Commercial grade lipases from Rhizopus javanicus (FAP-15) and Candida rugosa (AY-30) were a gift from Amano International Enzyme Co. (Troy, VA). Specific activity of the lipases under standard aqueous (bulk) conditions were 58.9 units and 8.9 units per $\mathrm{mg}$, respectively. One unit is the amount of enzyme required to hydrolyze $1 \mu \mathrm{M}$ triglyceride/minute. Clarified milk fat (saponification value $=229.2$ ) was purchased from Level Valley Dairy (West Bend, WI). Soybean lecithin (Centrophase-C, 6002) containing 55\% phospholipids (acetone insolubles) was a gift from Central Soya Co. (Fort Wayne, IN). HPLC grade acetone was purchased from Fisher Scientific Co. (Fair Lawn, NJ). Oleic acid of $99.9 \%$ purity was obtained from Sigma Chemical Co. (St. Louis, $\mathrm{MO}$ ), and was used as a standard. Benzene and pyridine of spectrophotometric grade were purchased from Aldrich Chemical Co. (Milwaukee, WI). Anhydrous glycerol (calibration standard) and n-tetradecane (internal standard) were purchased from Fluka (Ronkonkoma, NY). The other calibration standards for free fatty acids (FFA), monoacylglycerols (MAG) and diacylglycerols (DAG) were purchased from NuCheckPrep (Elysian, MN). All other reagents were analytical grade.

\section{Preparation of reverse micellar media}

A $55.6 \mathrm{mM}$ stock solution of soybean lecithin (avg mol wt 780) in milk fat was prepared and stored at room temperature until further use. Reverse micellar media of various compositions were prepared by mixing appropriate volumes of milk fat and the stock solution of lecithin in milk fat in batch reactors of $10 \mathrm{~mL}$ volume. The desired enzyme concentration and molar ratios of water to phospholipids (R) were obtained by injecting appropriate volumes of buffer solution and the concentrated buffered enzyme stock solution using a positive displacement micropipettor. The true value of $\mathrm{R}$ may be higher due to hydrated state of phospholipids in commercial preparations. After adding enzyme solution, the micellar solutions were mixed on a Vortex stirrer until a clear single-phase medium was formed.

\section{Hydrolysis of milk fat in reverse micellar media}

The reaction media with substrate were equilibrated to appropriate temperatures before addition of enzyme solution. The hydrolysis of milk fat was initiated by injecting the enzyme solution and Vortex-mixing until the media became clear. At predetermined time intervals, appropriate volumes $(10-100 \mu \mathrm{L})$ of reaction mixtures were transferred into $15-\mathrm{mL}$ screw-cap tubes containing a predetermined volume of benzene, producing a total volume of $5 \mathrm{~mL}$. The tubes were immediately Vortexmixed to stop the enzyme reaction and stored until later measured for liberated fatty acids. Also, at predetermined time intervals, $0.2 \mathrm{~mL}$ reaction mixtures were transferred into 4-mL screw-cap glass vials containing $1 \mathrm{~mL}$ acetone (containing $3 \mathrm{mg} / \mathrm{mL}$ of internal standard, n-tetradecane) and stored in freezer until later analysis of hydrolysates by gas chromatography. 
Table 1-Variable-level combinations for 3-variable rotatable central composite design

\begin{tabular}{|c|c|c|c|c|c|}
\hline & \multicolumn{5}{|c|}{ Reaction parameters (independent variables) } \\
\hline & \multirow[b]{2}{*}{$\mathrm{pH}$} & \multirow[b]{2}{*}{$\begin{array}{c}\mathrm{R}= \\
\frac{\text { [water] }}{\text { [surfactant] }}\end{array}$} & \multicolumn{3}{|c|}{ Temperature $\left({ }^{\circ} \mathrm{C}\right)$} \\
\hline & & & $\begin{array}{c}\text { Lipase } \\
\text { FAP-15 } \\
\text { (R.javanicus) }\end{array}$ & & $\begin{array}{c}\text { Lipase } \\
\text { AY-30 } \\
\text { (C. rugosa) }\end{array}$ \\
\hline $\begin{array}{c}\text { Coded levels } \\
-1.682(-\alpha) \\
-1 \\
0 \\
1 \\
1.682(\alpha)\end{array}$ & $\begin{array}{l}3.0 \\
4.0 \\
5.5 \\
7.0 \\
8.0\end{array}$ & $\begin{array}{r}4.6 \\
8.0 \\
13.0 \\
18.0 \\
21.4\end{array}$ & $\begin{array}{l}46.5 \\
52.0 \\
60.0 \\
68.0 \\
73.5\end{array}$ & & $\begin{array}{l}36.5 \\
42.0 \\
50.0 \\
58.0 \\
63.5\end{array}$ \\
\hline $\begin{array}{l}\text { Experimental design } \\
\text { points }{ }^{\mathrm{a}} \\
\text { Cubic points }\left(\mathrm{n}_{\mathrm{c}}\right) \\
1 \\
2 \\
3 \\
4 \\
5 \\
6 \\
7 \\
8\end{array}$ & $\begin{array}{r}-1 \\
1 \\
-1 \\
1 \\
-1 \\
1 \\
-1 \\
1\end{array}$ & $\begin{array}{r}-1 \\
-1 \\
1 \\
1 \\
-1 \\
-1 \\
1 \\
1\end{array}$ & & $\begin{array}{r}-1 \\
-1 \\
-1 \\
-1 \\
1 \\
1 \\
1 \\
1\end{array}$ & \\
\hline $\begin{array}{c}\text { Axial points }\left(\mathrm{n}_{\mathrm{a}}\right) \\
9 \\
10 \\
11 \\
12 \\
13 \\
14\end{array}$ & $\begin{array}{c}-1.682 \\
1.682 \\
0 \\
0 \\
0 \\
0\end{array}$ & $\begin{array}{c}0 \\
0 \\
-1.682 \\
1.682 \\
0 \\
0\end{array}$ & & $\begin{array}{c}0 \\
0 \\
0 \\
0 \\
-1.682 \\
1.682\end{array}$ & \\
\hline $\begin{array}{l}\text { Center point }\left(\mathrm{n}_{\mathrm{o}}\right) \\
15\end{array}$ & 0 & 0 & & 0 & \\
\hline $\begin{array}{c}\text { Additional points } \\
1 \\
2 \\
3 \\
4 \\
5 \\
6\end{array}$ & $\begin{array}{r}-1 \\
1 \\
0 \\
0 \\
0 \\
0\end{array}$ & $\begin{array}{r}0 \\
0 \\
-1 \\
1 \\
0 \\
0\end{array}$ & & $\begin{array}{r}0 \\
0 \\
0 \\
0 \\
-1 \\
1\end{array}$ & \\
\hline
\end{tabular}

a Center point $\left(n_{0}\right)$ was replicated six times and entire experiment was replicated twice. The additional points were excluded from second-order model fitting.

\section{Determination of initial rate and degree of hydrolysis}

The liberated free fatty acids were quantified using a method described by Lowry and Tinsley (1976). Cupric acetate-pyridine reagent $(1 \mathrm{~mL})$ was added to $15-\mathrm{mL}$ screw-cap tubes containing $5 \mathrm{~mL}$ mixture of reaction medium and benzene. The tubes were then shaken for 2 min using an oscillating shaker. After 5 min centrifugation at $3300 \mathrm{rpm}(1200 \times$ $g$ ), absorbance of the supernatant was measured at $715 \mathrm{~nm}$. The concentration of liberated fatty acid was calculated from the standard curve generated using oleic acid as calibration standard.

Unless otherwise stated, the initial rate (activity) is expressed as $\mu$ mole of free fatty acid liberated/min under the assay condition based at $1 \mathrm{hr}$ reaction time. The kinetics of hydrolysis was linear up to 75-90 min under the conditions we used. The degree of hydrolysis or percent conversion was calculated as follows:

$$
\% \text { Degree of hydrolysis }=\frac{\text { Liberated fatty acids }}{\text { Total number of ester bonds }} \times 100
$$

The total number of ester bonds in TAG was estimated from the saponification value determined by standard procedure (AOAC, 1984). Unless otherwise stated, the degree of hydrolysis is expressed for $24 \mathrm{hr}$ reaction.

\section{Gas chromatography of milk fat hydrolysates}

A microprocessor-controlled PERKIN-ELMER 8410 gas chromatograph (Norwalk, CT) with on-column injector and flame ionization detector was used. The chromatograms were run with $2 \mathrm{~mm}$ i.d. and 1.83 $\mathrm{m}$ long glass column packed with $3 \%$ OV-17 on 100/120 mesh Supelcoport (Supelco, Bellefonte, PA). The flow rate of $\mathrm{N}_{2}$ carrier gas was 20 $\mathrm{mL} / \mathrm{min}$ with inlet pressure $275 \mathrm{kPa}$.

The trimethylsilyl derivatives of FFA, MAG, DAG, and glycerol in hydrolyzed fat were prepared using a 90:1 mixture of bis(trimethysilyl)trifluroacetamide:trimethylchlorosilane (Sylon-BFT, Supelco, Bellefonte, PA)) reagent. About $0.25 \mathrm{~mL}$ of the mixtures, containing milk fat hydrolysate and internal standard, were transferred to
Table 2-Regression coefficients and coefficients of determination $\left(R^{2}\right)$ of second-order fitted equation for lipase-catalyzed hydrolysis of milk fat in phospholipid/TAG reverse micellar media ${ }^{a}$

\begin{tabular}{|c|c|c|c|c|}
\hline \multirow[b]{2}{*}{ Variable } & \multicolumn{2}{|c|}{ Initial rate } & \multicolumn{2}{|c|}{ Degree of hydrolysis } \\
\hline & $\begin{array}{c}\text { Lipase } \\
\text { FAP-15 } \\
\text { (R. javanicus) }\end{array}$ & $\begin{array}{c}\text { Lipase } \\
\text { AY-30 } \\
\text { (C. rugosa) }\end{array}$ & $\begin{array}{c}\text { Lipase } \\
\text { FAP-15 } \\
\text { (R. javanicus) }\end{array}$ & $\begin{array}{c}\text { Lipase } \\
\text { AY-30 } \\
\text { (C. rugosa) }\end{array}$ \\
\hline $\begin{array}{l}\text { Intercept }\left(\beta_{0}\right) \\
\text { Linear }\end{array}$ & 32.614 & 13.822 & 27.298 & 10.700 \\
\hline$R\left(\beta_{1}\right)$ & $4.492 * *$ & 0.598 & $2.728 * *$ & 0.232 \\
\hline$P\left(\beta_{2}\right)$ & -1.544 & $1.543^{* *}$ & -0.483 & 0.387 \\
\hline $\mathrm{T}\left(\beta_{3}\right)$ & -1.625 & 0.136 & $-3.816 * *$ & $-1.359^{*}$ \\
\hline $\begin{array}{l}\text { Quadratic } \\
R \times R\left(\beta_{11}\right) \\
P \times P\left(\beta_{22}\right) \\
T \times T\left(\beta_{33}\right)\end{array}$ & $\begin{array}{l}-5.025^{* *} \\
-4.905^{* *} \\
-7.053^{*}\end{array}$ & $\begin{array}{l}-2.450 * * \\
-2.810^{* *} \\
-1.186^{*}\end{array}$ & $\begin{array}{l}-2.727^{* *} \\
-0.268 \\
-3.958^{* *}\end{array}$ & $\begin{array}{l}-1.415^{*} \\
-1.538^{* *} \\
-0.910^{*}\end{array}$ \\
\hline $\begin{array}{l}\text { Interaction } \\
R \times P\left(\beta_{12}\right) \\
P \times T\left(\beta_{23}\right) \\
T \times R\left(\beta_{31}\right)\end{array}$ & $\begin{array}{l}-0.104 \\
-3.000^{*} \\
-2.073^{*}\end{array}$ & $\begin{array}{r}-0.480 \\
-0.339 \\
0.209\end{array}$ & $\begin{array}{l}-0.672 \\
-1.214 \\
-3.600^{* *}\end{array}$ & $\begin{array}{l}-0.253 \\
-0.360 \\
-0.465\end{array}$ \\
\hline $\begin{array}{l}\text { Lack of fit } \\
R^{2}\end{array}$ & $\begin{array}{l}\text { NS } \\
0.92^{* *}\end{array}$ & $\begin{array}{l}\text { NS } \\
0.92^{* *}\end{array}$ & $\begin{array}{l}\text { NS } \\
0.90^{* *}\end{array}$ & $\begin{array}{c}* * \\
0.76 * *\end{array}$ \\
\hline
\end{tabular}

a The second-order function is: $\hat{Y}=\beta_{0}+\beta_{1} R+\beta_{2} P+\beta_{3} T+\beta_{11} R^{2}+\beta_{22} P^{2}+\beta_{33}+$ $\mathrm{T}^{2}+\beta_{12} \mathrm{RP}+\beta_{23} \mathrm{PT}+\beta_{31} \mathrm{TR}$; where, $\mathrm{P}=\mathrm{pH}, \mathrm{R}=$ [water]/[surfactant], and $\mathrm{T}=$ temperature.

* Significant $(P<0.05)$; * Significant $(P<0.01)$; NS Nonsignificant $(P>0.05)$.

Table 3-Lipase-catalyzed hydrolysis of milk fat in phospholipid/TAG reverse micellar media at various reaction conditions

\begin{tabular}{|c|c|c|c|c|c|c|}
\hline \multicolumn{3}{|c|}{$\begin{array}{c}\text { Reaction } \\
\text { parameters }^{a}\end{array}$} & \multicolumn{2}{|c|}{$\begin{array}{c}\text { Initial rate }{ }^{b} \\
(\mu \text { moles FFA/min })\end{array}$} & \multicolumn{2}{|c|}{$\begin{array}{c}\text { Degree of hydrolysis }{ }^{b} \\
(\%)\end{array}$} \\
\hline $\begin{array}{c}\mathrm{T} \\
\left({ }^{\circ} \mathrm{C}\right)\end{array}$ & $\mathrm{pH}$ & $\mathrm{R}$ & $\begin{array}{c}\text { Lipase } \\
\text { FAP-15 } \\
\text { (R. javanicus) }\end{array}$ & $\begin{array}{c}\text { Lipase } \\
\text { AY-30 } \\
\text { (C. rugosa) }\end{array}$ & $\begin{array}{c}\text { Lipase } \\
\text { FAP-15 } \\
\text { (R. javanicus) }\end{array}$ & $\begin{array}{c}\text { Lipase } \\
\text { AY-30 } \\
\text { (C. rugosa) }\end{array}$ \\
\hline \multirow{4}{*}{$\begin{array}{c}52 \\
(42)^{c}\end{array}$} & 4 & 8 & $9.6 \pm 0.2$ & $4.0 \pm 0.0$ & $18.6 \pm 0.4$ & $6.1 \pm 0.0$ \\
\hline & & 18 & $16.4 \pm 0.3$ & $5.5 \pm 0.1$ & $28.1 \pm 0.5$ & $6.6 \pm 0.1$ \\
\hline & 7 & 8 & $9.7 \pm 0.1$ & $8.9 \pm 0.2$ & $18.5 \pm 0.3$ & $8.3 \pm 0.2$ \\
\hline &  & $\begin{array}{r}18 \\
8\end{array}$ & $\begin{array}{l}23.1 \pm 0.4 \\
16.8 \pm 0.4\end{array}$ & $\begin{array}{l}7.0 \pm 0.1 \\
5.5 \pm 0.1\end{array}$ & $\begin{array}{l}29.3 \pm 0.5 \\
21.0 \pm 0.5\end{array}$ & $\begin{array}{l}7.4 \pm 0.0 \\
5.7 \pm 0.1\end{array}$ \\
\hline \multirow[t]{2}{*}{$\begin{array}{c}68 \\
(58)^{c}\end{array}$} & & $\begin{array}{r}18 \\
8\end{array}$ & $\begin{array}{l}22.4 \pm 0.1 \\
12.0 \pm 0.2\end{array}$ & $\begin{array}{l}6.4 \pm 0.1 \\
7.5 \pm 0.1\end{array}$ & $\begin{array}{l}20.1 \pm 0.1 \\
20.0 \pm 0.3\end{array}$ & $\begin{array}{l}3.9 \pm 0.1 \\
6.0 \pm 0.1\end{array}$ \\
\hline & $\gamma$ & 18 & $10.0 \pm 0.2$ & $8.0 \pm 0.1$ & $12.5 \pm 0.3$ & $3.7 \pm 0.0$ \\
\hline
\end{tabular}

${ }^{a}$ Reaction parameters: phospholipid concentration $=50 \mathrm{mM}$, enzyme concentration = $5 \mathrm{mg} / 10 \mathrm{~mL}$ reaction mixture, substrate concentration $=95.4 \% \mathrm{v} / \mathrm{v}$ at $\mathrm{R}=8$ and $94.5 \%$ $\mathrm{v} / \mathrm{v}$ at $\mathrm{R}=18$; buffers: $50 \mathrm{mM}$ citrate-phosphate buffer for $\mathrm{pH} 4$ and $50 \mathrm{mM} \mathrm{Na-K}$ phosphate buffer for $\mathrm{pH} 7$.

Mean \pm standard deviation.

${ }^{c}$ Values in parenthesis are the reaction temperature for Lipase AY-30.

2-mL screw-cap reaction vials. The solvents were evaporated to dryness under a stream of $\mathrm{N}_{2}$. Sylon-BFT $(0.25 \mathrm{~mL})$, a silylating reagent, was added and after closing the vials, they were briefly warmed on a heating block, stirred vigorously for a few sec, and heated at $85^{\circ} \mathrm{C}$ for $25 \mathrm{~min}$. The vials were allowed to cool to room temperature. After $1 \mathrm{hr}$, about $1 \mu \mathrm{L}(\approx 50 \mu \mathrm{g}$ hydrolysates) of derivatized mixtures was injected at $75^{\circ} \mathrm{C}$. After an isothermal period of $2 \mathrm{~min}$, the column temperature was raised to $225^{\circ} \mathrm{C}$ at $25^{\circ} \mathrm{C} / \mathrm{min}$ and then to $315^{\circ} \mathrm{C}$ at $9^{\circ} \mathrm{C} / \mathrm{min}$. Finally, temperature was raised to $355^{\circ} \mathrm{C}$ at $1{ }^{\circ} \mathrm{C} / \mathrm{min}$ and was held at $355^{\circ} \mathrm{C}$ for $6 \mathrm{~min}$. The injector was $370^{\circ} \mathrm{C}$ and detector was $375^{\circ} \mathrm{C}$.

Qualitative and quantitative chromatographic analyses were performed by internal standardization using n-tetradecane as internal standard. The peaks in the chromatogram were identified and quantified according to acyl carbon number (ACN) for each class of lipid: FFA, MAG, and DAG. The relative retention time (RRT) and response factor (RF) were determined using various classes of calibration mixture from $\mathrm{Nu}$ Check Prep. Inc. (Elysian, MN). The FFA mixture contained standards from AC4 to AC18. The MAG mixture contained standards from AC12 to $\mathrm{AC} 18$. The DAG mixture contained AC16, AC24, AC28, AC32, and AC36 standards. The RRT and RF for other peaks were determined by interpolation.

The relative retention time was calculated as follows:

$\mathrm{RRT}(\mathrm{I})=$ retention time of ith component/retention time of internal standard

The response factors were calculated as follows: 


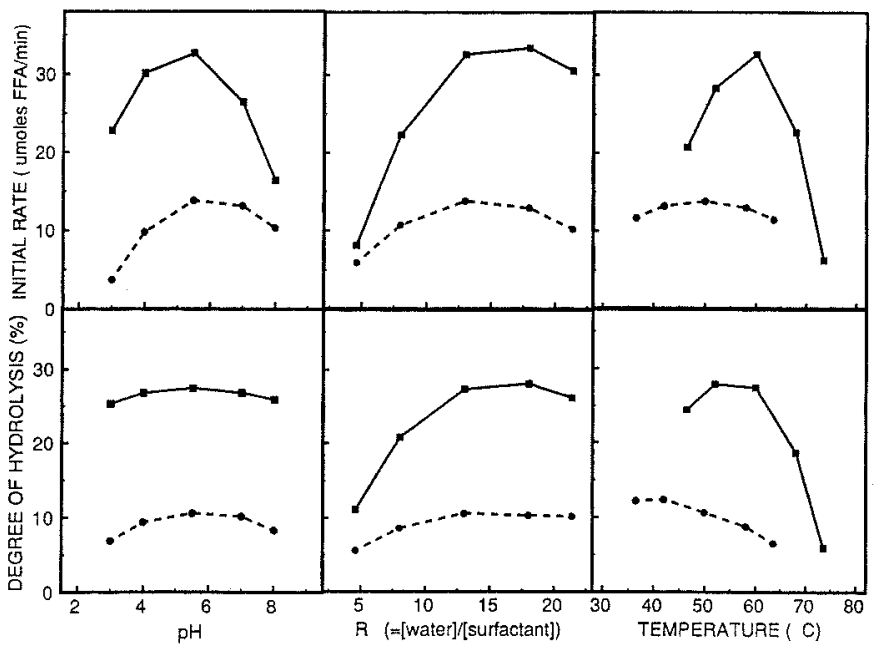

Fig. 1-Effect of $\mathrm{pH}$, molar ratio of water to surfactant (R), and temperature on the initial rate and degree of hydrolysis for $R$. javanicus and $C$. rugosa lipase catalyzed hydrolysis of milk triacylglycerols in solvent-free phospholipid reverse micellar media. Reaction parameters: $\mathrm{pH} 5.5$ (50 mM citrate-phosphate buffer), $\mathrm{R}$ $=13$, temperature $=60^{\circ} \mathrm{C}$ for $R$. javanicus lipase and $50^{\circ} \mathrm{C}$ for $\mathrm{C}$. rugosae lipase, phospholipid concentration $=50 \mathrm{mM}$, enzyme concentration $=5 \mathrm{mg} / 10 \mathrm{~mL}$ reaction mixture. $R$. javanicus, () lipase, C. rugosa (----).

$$
\mathrm{RF}(\mathrm{I})=\mathrm{W}(\mathrm{I}) \times \mathrm{A}(\text { is }) / \mathrm{W}(\text { is }) \times \mathrm{A}(\mathrm{I})
$$

where $\mathrm{W}(\mathrm{I})=$ weight of ith component; $\mathrm{W}($ is $)=$ weight of internal standard; $\mathrm{A}(\mathrm{I})$ = peak area of ith component; $\mathrm{A}$ (is) = peak area of internal standard. These RF values were used to calculate the composition of sample as follows:

$$
\% \mathrm{~W}(\mathrm{I})=\mathrm{A}(\mathrm{I}) \times \mathrm{RF}(\mathrm{I}) \times \mathrm{W}(\text { is }) \times 100 / \mathrm{A}(\text { is }) \times \mathrm{W}(\mathrm{s})
$$

where $\% \mathrm{~W}(\mathrm{I})=$ weight percent of ith component; $\mathrm{W}(\mathrm{s})=$ weight of sample.

\section{Experimental design}

Validation of initial reaction velocities was reported (Patel et al., 1995). To examine the effects of temperature, $\mathrm{pH}$, and molar ratio of water to surfactant $(\mathrm{R})$ on the lipase-catalyzed hydrolysis and on the content and composition of end products, a rotatable central composite design (Box and Wilson, 1951) was adopted with three-variable and fivelevel pattern (Table 1). The total number of observations was 20 , which included eight factorial (cubic) points, six axial points, and six centerpoint replicates. The axial points represented the extreme high and low values of independent variables (reaction conditions). The entire design was replicated twice. The data were fit to the second order function as follows:

$$
Y_{i}=\beta_{0}+\Sigma \beta_{i} X_{i}+\Sigma \beta_{i i} X_{i}^{2}+\Sigma \beta_{i i} X_{i} X_{j}
$$

where $Y_{i}=$ initial rate or degree of hydrolysis; $X_{i}$ and $X_{\mathrm{j}}=$ independent variables $(\mathrm{pH}$, temperature, or $\mathrm{R}) ; \beta_{0}=$ center point of system; $\beta_{\mathrm{i}}=$ coefficient of linear effects of reaction; $\beta_{\mathrm{ii}}=$ coefficient of quadratic effects of reaction parameters; $\beta_{i j}=$ coefficient of interactive effects of reaction parameters.

In addition to the 20 experimental points, six additional points (Table 1) representing +1 and -1 coded levels of each reaction condition were studied to provide a complete set of five observations. These observations were made to assess the effects of each variable on the lipase reaction, as studied over the entire range of variable levels at a fixed level of all other variables.

\section{Statistical analysis}

The coefficient of each parameter in the model was determined by General Linear Model (GLM) procedure using Minitab (1990) statistical software. The three-dimensional surface plots, showing effects of tworeaction conditions (holding all others constant), were generated by Axum (1989) graphical software using the GLM regression model. Optimum reaction condition ranges were determined by the 3 -factor Taylor

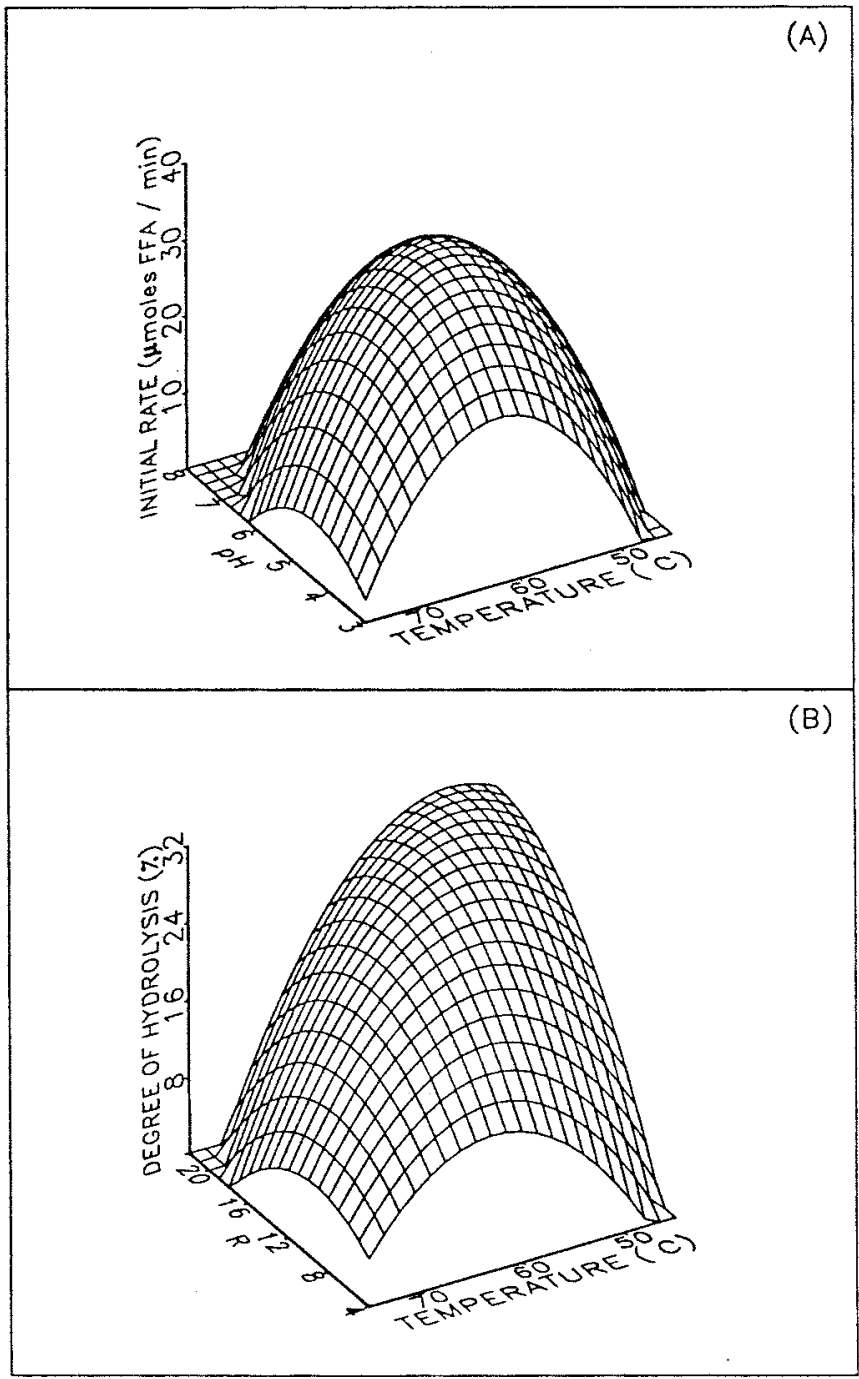

Fig. 2-Interactive effects of reaction parameters on hydrolysis of milk triacylglycerols by $R$. javanicus lipase in solvent-free reverse micellar media. Reaction parameters: phospholipid concentration $=50 \mathrm{mM}$, substrate concentration $=94.5 \%$, v/v, enzyme concentration $=5 \mathrm{mg} / 10 \mathrm{~mL}$.

Table 4-Optimum reaction conditions for lipase-catalyzed hydrolysis of milk fat in phospholipid/TAG reverse micellar media ${ }^{a}$

\begin{tabular}{lcc}
\hline Reaction conditions & $\begin{array}{c}\text { Lipase FAP-15 } \\
\text { (R. javanicus) }\end{array}$ & $\begin{array}{c}\text { Lipase AY-30 } \\
\text { (C. rugosa) }\end{array}$ \\
\hline $\mathrm{R}=\frac{\text { [Water] }}{[\text { Phospholipids] }}$ & $14-16$ & $13-14.5$ \\
$\mathrm{pH}$ & $5-6$ & $5.5-6$ \\
Temperature $\left({ }^{\circ} \mathrm{C}\right)$ & $58-60$ & $45-47$ \\
\hline
\end{tabular}

a Determined using three-factor Taylor polynomial optimization for the initial rate and degree of hydrolysis.

polynomial optimization program using Design-Expert (1988) statistical software. Where applicable, results were analyzed by the ANOVA procedure using Minitab (1990) software, and significant differences were determined using Fisher's test.

\section{RESULTS \& DISCUSSION}

TRIACYLGLYCEROLS can be hydrolyzed in solvent-free reverse micellar media comprising a highly purified lecithin as a surfactant, TAG as continuous non-polar phase and substrate, and purified lipase as a biocatalyst (Chen and Pai, 1991; Patel, 1993). Further possibility of using available, natural lecithin to form reverse micelles for bioconversion of milk fat to multi- 


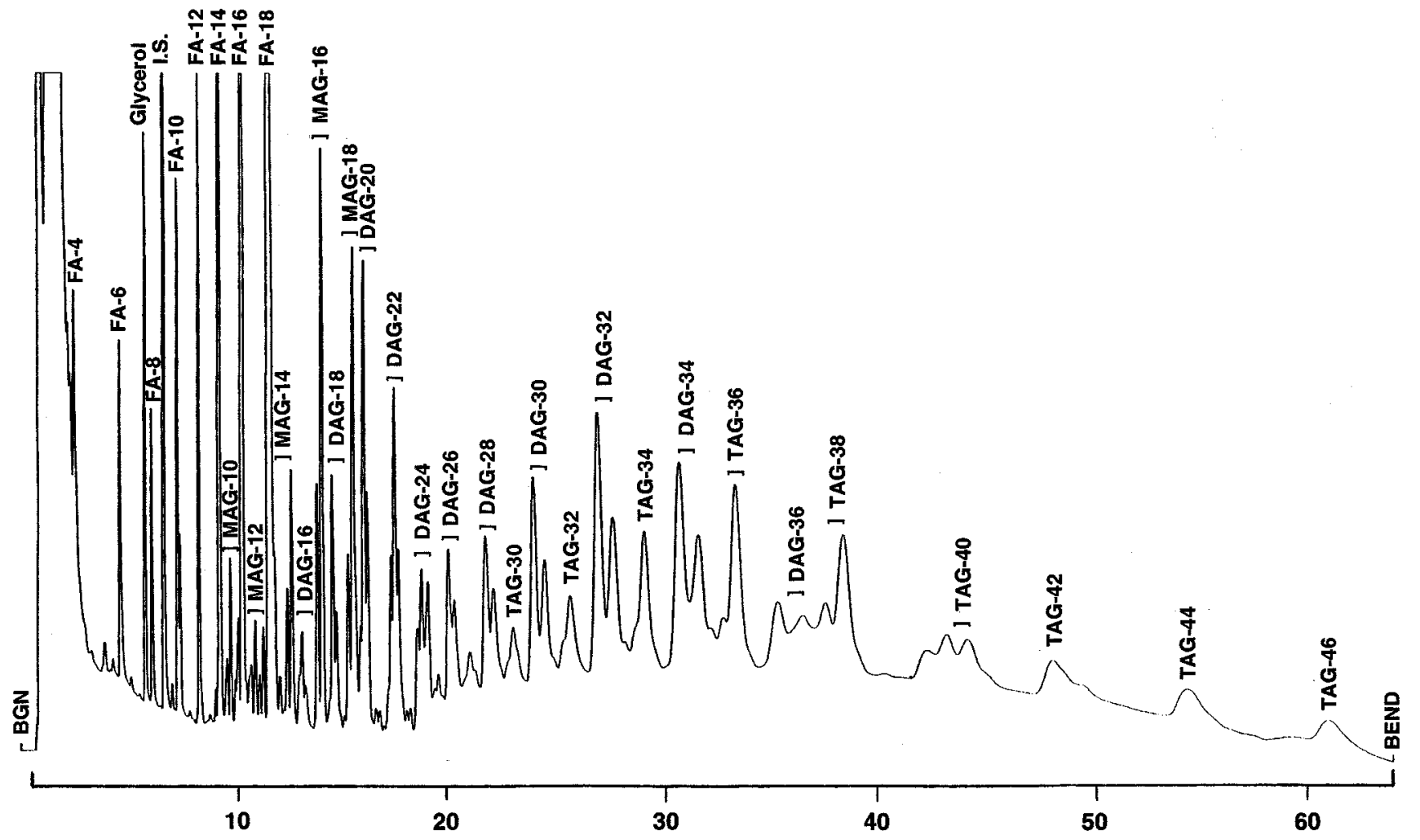

RETENTION TIME (min)

Fig. 3-Gas chromatogram of milk triacylglycerol hydrolyzate prepared by $\boldsymbol{R}$. javanicus lipase catalyzed hydrolysis in solvent-free phospholipid reverse micellar media. Chromatography on $1.83 \times 2 \mathrm{~mm}$ i.d. glass column packed with $3 \%$ OV-17. Peak designations: $\mathrm{FA}=$ fatty acids, MAG = monoacylglycerols, DAG = diacylglycerols, TAG = triacylglycerols. The numbers indicate the acyl carbon number components.

functional food ingredients was examined. Natural lecithin occurs as a mixture of phospholipids. Because of the difficulty in separation of its components, natural lecithin is used as a mixture. Lipase could be solubilized in the reverse micelles of soybean lecithin in milk fat, yielding clear isotropic solutions.

Milk fat hydrolysis in that system did not require continuous agitation; and the system remained clear throughout the reaction without any visible phase separation.

\section{Effect of reaction parameters on milk fat hydrolysis}

Lipase-mediated hydrolytic reactions in reverse micellar media have been critically influenced by molar ratio of water to surfactant $(\mathrm{R})$, reaction temperature and reaction $\mathrm{pH}$ (Scmidli and Luisi, 1990; Stark et al., 1991). The effects of such conditions on the initial rate and degree of hydrolysis for $R$. javanicus and $C$. rugosa lipase-catalyzed hydrolysis of milk fat in phospholipid reverse micellar media were compared (Fig. 1).

The $\mathrm{pH}$-activity profiles for both enzymes in the range $\mathrm{pH} 3$ to 8 were the typical bell-shaped profiles for most enzymes in aqueous systems. The reaction $\mathrm{pH}$ is $\mathrm{pH}$ of the buffer for preparation of enzyme solution and medium. Both enzymes exhibited maximum reaction rates and degree of hydrolysis at about $\mathrm{pH} 5.5$ for hydrolysis of milk fat. However, no difference was observed in degree of hydrolysis in pH range 3 to 8 when milk fat was hydrolyzed by $R$. javanicus lipase. The $\mathrm{pH}$ maximum in the solvent-free phospholipid reverse micellar medium was considerably lower than that in Aerosol-OT reverse micellar medium or the aqueous emulsion system (Han and Rhee, 1986).

Lipase activity in reverse micellar medium is dependent on $\mathrm{R}$ because properties of water in the aqueous pool of and in the enzyme microenvironment differ considerably at different $\mathrm{R}$ values (Gupte et al., 1995). The function of water in the enzymatic reactions in nonpolar solvents is not fully understood; however, it has been discussed in terms of hydration of enzyme (Klibanov, 1986; Yamane et al., 1988; Zaks and Klibanov, 1988; Han et al., 1990; Hirata et al., 1990). The R-activity profile for both enzymes exhibited a bell-shaped curve with maximum rate at $\mathrm{R}$ $=18$ for $R$. javanicus lipase and $\mathrm{R}=13$ for $C$. rugosa lipase. Chen and Pai (1991) reported that an R value of 10 was necessary for the maximum activity of enzyme in an lecithin-butteroil-water reverse micellar system. The higher value in our study may have been due to the commercial grade lecithin and enzyme used. The compounds included in the water pool as impurities may complete for the water, thereby reducing available water. The R-activity profiles in solvent-free phospholipid reverse micellar media are considerably different from those in Aerosol-OT reverse micellar media (Han and Rhee, 1986; Kim and Chung, 1989).

The rate and the degree of hydrolysis of milk fat were maximum between $50^{\circ}$ and $60^{\circ} \mathrm{C}$ for $R$. javanicus lipase and between $40^{\circ}$ and $50^{\circ} \mathrm{C}$ for C. rugosa lipase. Activity above those temperatures was reduced, presumably due to thermal denaturation of enzyme. Activity below those temperatures was reduced, possibly due to an increase in viscosity of oil phase and co-existence of another phase at the lower temperature extreme. Both enzymes exhibited unusually high thermal stability as evidenced by the temperature optimum at a considerably higher value and the significant activity at the extreme temperature of about $74^{\circ} \mathrm{C}$ for $R$. javanicus lipase and $64^{\circ} \mathrm{C}$ for $C$. rugosa lipase. Enhanced thermal stability in this medium could be due to a difference between properties of water in the core of micelles and those of bulk water in aqueous solution. These could also be due to the protection of enzyme from temperature-induced denaturation by nonspecific interactions with lipids or phospholipids in the medium. 
Table 5-Yield of various components for hydrolysis of milk fat by lipase FAP-15 ( $R$. javanicus) in the solvent-free reverse micellar media of phospholipids in TAG

\begin{tabular}{|c|c|c|c|c|c|c|c|c|c|c|}
\hline \multirow[b]{2}{*}{ Variable $^{a}$} & \multicolumn{10}{|c|}{ Components in milk fat hydrolysates ${ }^{b}$} \\
\hline & Glycerol & SCFFA & LCFFA & $\begin{array}{l}\text { Total } \\
\text { FFA }\end{array}$ & $\begin{array}{c}s n-2 \\
\text { MAG }\end{array}$ & $\begin{array}{c}s n-1(3) \\
\text { MAG }\end{array}$ & $\begin{array}{l}\text { Total } \\
\text { MAG }\end{array}$ & $\begin{array}{c}s n-1,2(2,3) \\
\text { DAG }\end{array}$ & $\begin{array}{l}s n-1,3 \\
\text { DAG }\end{array}$ & $\begin{array}{l}\text { Total } \\
\text { DAG }\end{array}$ \\
\hline $\begin{array}{l}\text { Intercept }\left(\beta_{0}\right) \\
\quad \text { Linear }\end{array}$ & 0.394 & 2.528 & 22.697 & 25.224 & 0.857 & 3.918 & 4.778 & 10.349 & 14.106 & 24.465 \\
\hline $\begin{array}{l}R\left(\beta_{1}\right) \\
P\left(\beta_{2}\right) \\
T\left(\beta_{3}\right)\end{array}$ & $\begin{array}{c}0.058^{*} \\
0.006 \\
-0.043^{*}\end{array}$ & $\begin{array}{l}0.226^{*} \\
-0.068 \\
-0.299^{* *}\end{array}$ & $\begin{aligned} & 1.588^{*} \\
-0.060 & \\
- & 2.752^{* *}\end{aligned}$ & $\begin{array}{l}1.814^{*} \\
-0.129 \\
-3.052^{* *}\end{array}$ & $\begin{array}{l}0.053 \\
-0.008 \\
-0.386 * *\end{array}$ & $\begin{array}{l}0.283^{*} \\
-0.072 \\
-0.366^{* *}\end{array}$ & $\begin{array}{c}0.336^{*} \\
-0.080 \\
-0.754^{* *}\end{array}$ & $\begin{array}{l}-0.007 \\
0.040 \\
-2.519 * *\end{array}$ & $\begin{array}{r}0.440 \\
-0.166 \\
0.563\end{array}$ & $\begin{array}{c}0.434 \\
-0.127 \\
-1.956 * *\end{array}$ \\
\hline $\begin{array}{l}\text { Quadratic } \\
\mathrm{R} \times \mathrm{R}\left(\beta_{11}\right) \\
\mathrm{P} \times \mathrm{P}\left(\beta_{22}\right) \\
\mathrm{T} \times \mathrm{T}\left(\beta_{33}\right)\end{array}$ & $\begin{array}{l}-0.053^{*} \\
-0.014 \\
-0.088^{* *}\end{array}$ & $\begin{array}{l}-0.312^{* *} \\
-0.075 \\
-0.445^{* *}\end{array}$ & $\begin{array}{l}-2.752^{* *} \\
-0.371 \\
-3.316^{* *}\end{array}$ & $\begin{array}{l}-3.063^{* *} \\
-0.446 \\
-3.761 * *\end{array}$ & $\begin{array}{l}-0.093^{* *} \\
0.011 \\
0.013\end{array}$ & $\begin{array}{l}-0.642 * * \\
-0.154 \\
-0.829^{* *}\end{array}$ & $\begin{array}{l}-0.737^{* *} \\
-0.142 \\
-0.817^{* *}\end{array}$ & $\begin{array}{c}-0.766^{*} \\
-0.219 \\
0.111\end{array}$ & $\begin{array}{l}-1.771^{* *} \\
-0.638 \\
-2.245^{* *}\end{array}$ & $\begin{array}{l}-2.541^{* *} \\
-0.862 \\
-2.136^{* *}\end{array}$ \\
\hline $\begin{array}{l}\text { Interaction } \\
\quad \mathrm{R} \times \mathrm{P}\left(\beta_{12}\right) \\
\mathrm{P} \times \mathrm{T}\left(\beta_{23}\right) \\
\mathrm{T} \times \mathrm{R}\left(\beta_{31}\right)\end{array}$ & $\begin{array}{l}-0.010 \\
-0.018 \\
-0.050\end{array}$ & $\begin{array}{c}0.046 \\
-0.149 \\
-0.406^{* *}\end{array}$ & $\begin{array}{l}-0.128 \\
-1.098 \\
-2.302 *\end{array}$ & $\begin{array}{l}-0.084 \\
-1.249 \\
-2.709 * *\end{array}$ & $\begin{array}{c}0.012 \\
-0.040 \\
-0.142 *\end{array}$ & $\begin{array}{l}-0.079 \\
-0.179 \\
-0.421^{*}\end{array}$ & $\begin{array}{l}-0.066 \\
-0.219 \\
-0.564 * *\end{array}$ & $\begin{array}{l}-0.600 \\
-0.505 \\
-0.305\end{array}$ & $\begin{array}{l}-0.806 \\
-0.794 \\
-0.296\end{array}$ & $\begin{array}{l}-1.408 \\
-1.298 \\
-0.602\end{array}$ \\
\hline $\begin{array}{l}\text { Lack of fit } \\
R^{2}\end{array}$ & $\stackrel{*}{*}$ & $\begin{array}{l}\text { NS } \\
0.90\end{array}$ & $\begin{array}{l}\text { NS } \\
0.91\end{array}$ & $\begin{array}{l}\text { NS } \\
0.91\end{array}$ & $\begin{array}{l}\text { NS } \\
0.95\end{array}$ & $\begin{array}{l}\text { NS } \\
0.92\end{array}$ & $\begin{array}{l}\text { NS } \\
0.92\end{array}$ & $\begin{array}{l}\text { NS } \\
0.90\end{array}$ & $\stackrel{*}{*}$ & $\stackrel{*}{*}$ \\
\hline
\end{tabular}

a Regression coefficients and coefficients of determination $\left(R^{2}\right)$ of second-order fitted equation. The second-order function is: $\hat{Y}=\beta_{0}+\beta_{1} R+\beta_{2} P+\beta_{3} T+\beta_{11} R^{2}+\beta_{22} P^{2}+$ $\beta_{33} T^{2}+\beta_{12} R P+\beta_{23} P T+\beta_{31} T R ;$ where, $P=p H, R=[$ water $] /[$ surfactant $]$, and $T=$ temperature

b FFA = free fatty acids, SCFFA = short chain (C:4 - C:10) FFA, LCFFA = long chain (C:12 - C:18) FFA, MAG = monoacylglycerols, and DAG = diacylglycerols.

* Significant $(P<0.05)$; ${ }^{* *}$ Significant $(P<0.01)$; NS $=$ Nonsignificant $(P>0.05)$.

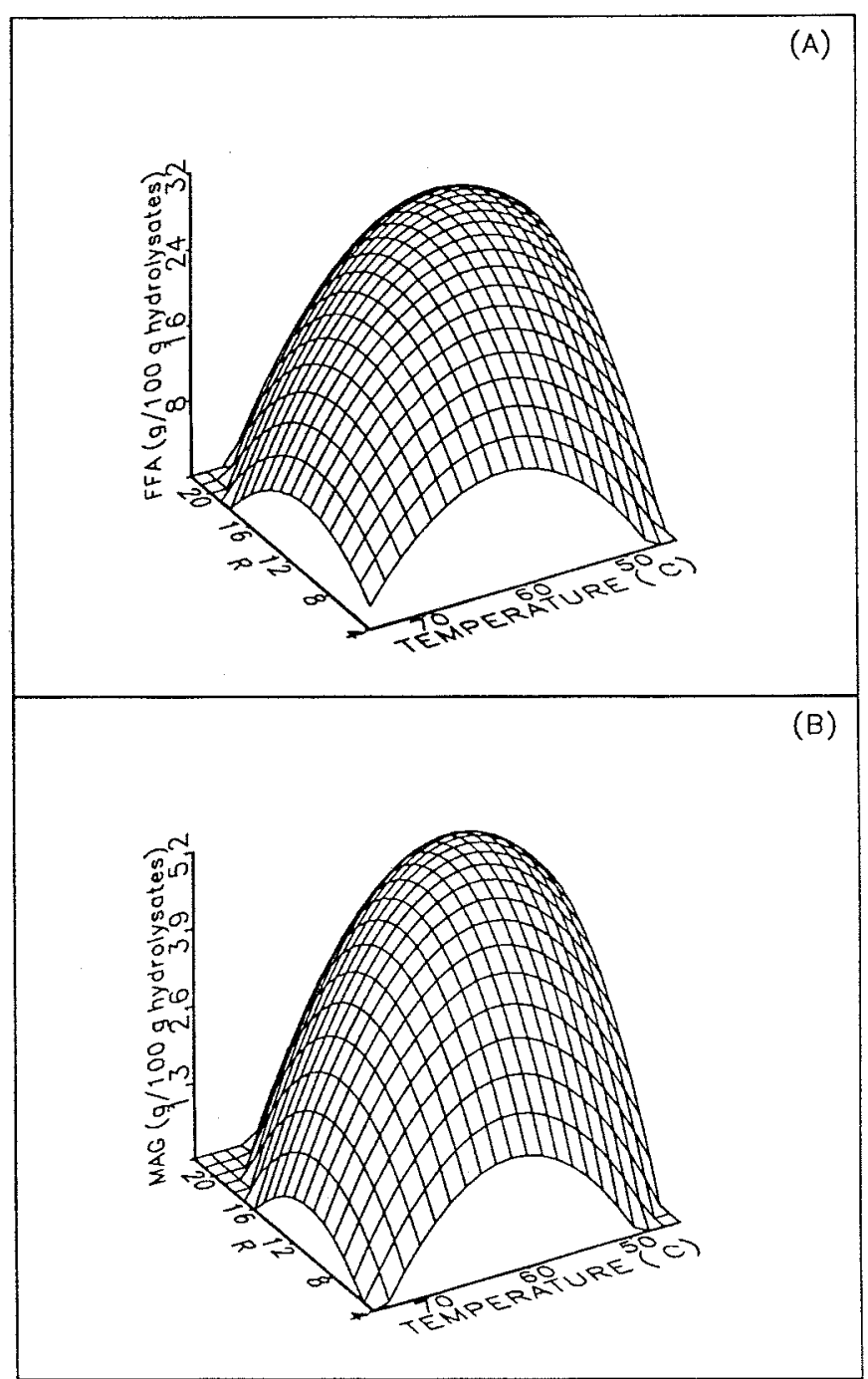

Fig. 4-Interactive effects of temperature and $R$ on free fatty acid and monoacylglycerol contents of milk triacylglycerol hydrolyzates prepared by $\boldsymbol{R}$. javanicus lipase catalyzed hydrolysis in solvent-free reverse micellar media. Reaction parameters: phospholipid concentration $=50 \mathrm{mM}$, substrate concentration $=$ $94.9 \% \mathrm{v} / \mathrm{v}, \mathrm{pH}=5.5$, enzyme concentration $=5 \mathrm{mg} / 10 \mathrm{~mL}$ reaction mixture.

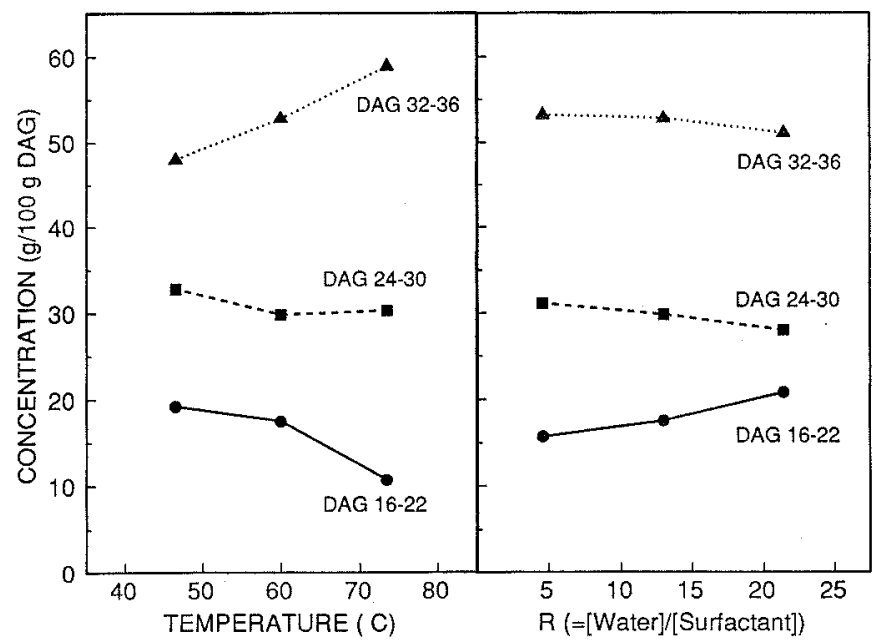

Fig. 5-Effect of temperature and $R$ on diacylglycerol contents of different acyl carbon number in milk triacylglycerol hydrolyzates prepared by $R$. javanicus lipase catalyzed hydrolysis in solventfree reverse micellar media. Reaction parameters: $\mathrm{pH}=5.5$ (50 $\mathrm{mM}$ citrate-phosphate buffer). Temperature $=60^{\circ} \mathrm{C}$, phospholipid concentration $=50 \mathrm{mM}$, substrate concentration $=95.7,94.9$, and $94.2 \%$, respectively at $R=4.6,13$, and 21.4 , respectively, enzyme concentration $=5 \mathrm{mg} / 10 \mathrm{~mL}$ reaction mixture. Diacylglycerol (DAG) 16-22, DAG 24-30 and DAG 32-36 represent total diacylglycerol contents from 16 to 22,24 to 30 , and 32 to 36 acyl carbon number, respectively.

Table 6-Optimum conditions for products of FAP-15 R. javanicus lipasecatalyzed hydrolysis of milk fat in phospholipid/TAG reverse micellar me$\mathrm{dia}^{\mathrm{a}}$

\begin{tabular}{lccc}
\hline & \multicolumn{3}{c}{ Reaction conditions } \\
\cline { 2 - 4 } Reaction products $^{\mathrm{b}}$ & $\mathrm{R}=\frac{\left[\mathrm{H}_{2} \mathrm{O}\right]}{[\text { Phospholipid] }}$ & $\mathrm{pH}$ & $\begin{array}{c}\text { Temp } \\
\left({ }^{\circ} \mathrm{C}\right)\end{array}$ \\
\hline Glycerol & 16 & $5-6$ & 57 \\
Total FFA & 16 & $5-6$ & 55 \\
Short-chain FFA & $20-21$ & $7-8$ & $49-51$ \\
Monoacylglycerol & $15-16$ & $5-6$ & 55 \\
Diacylglycerol & $11-13$ & $6-7$ & 55 \\
sn-1(3) MAG & $13-15$ & $4-6$ & $57-60$ \\
sn-2 MAG & $18-20$ & $6-8$ & $46-49$ \\
sn-1,3 DAG & $13-16$ & $4-6$ & $60-63$ \\
sn-1,2 (2,3) DAG & $11-16$ & $6-8$ & $46-49$ \\
\hline
\end{tabular}

a Determined by using three-factor Taylor polynomial optimization.

b FFA = free fatty acids, MAG = monoacylglycerols, and DAG = diacylglycerol 


\section{Dependence of milk fat hydrolysis on the interactive effects of reaction conditions}

Linear, quadratic and interactive influence of the reaction conditions on milk fat hydrolysis by $R$. javanicus and $C$. rugosa lipases were compared (Table 2) in the solvent-free phospholipid reverse micellar systems. Information on interactive effects on milk fat hydrolysis, by investigating several variables simultaneously, is very useful for commercial applications.

The initial rate and degree of hydrolysis for $R$. javanicus and C. rugosa lipase-catalyzed hydrolysis of milk fat at different reaction conditions were compared (Table 3 ). The interactive effects of reaction conditions are evident. In the case of $R$. javanicus lipase-mediated hydrolysis, the initial rate was lower at $\mathrm{pH} 4(16.4 \mu \mathrm{moles} / \mathrm{min})$ than that at $\mathrm{pH} 7(23.1 \mu \mathrm{moles} / \mathrm{min})$ when the reaction was carried out at $52^{\circ} \mathrm{C}$ (at $\mathrm{R}=18$ ). The initial rate was higher at $\mathrm{pH} 4(22.4 \mu$ moles $/ \mathrm{min})$ than that at pH 7 (10.0 $\mu$ moles $/ \mathrm{min})$, when the reaction was carried out at $68^{\circ} \mathrm{C}$ (at $\mathrm{R}=18$ ). The interactive influence of $\mathrm{pH}$ and temperature on the lipase reaction was evident (Fig. 2). The $\mathrm{pH}$ at which maximum activity occurs shifted towards higher values as temperature decreased.

\section{Optimization of reaction conditions for milk fat hydrolysis}

The GLM regression models were used to optimize reaction conditions maximizing both initial rate and degree of hydrolysis. The coefficients of linear, quadratic, and interactive effects of the reaction variables for the second-order fitted GLM regression model were compared (Table 2). The optimum ranges for conditions determined by three-factor Taylor polynomial optimization for milk fat hydrolysis in solvent-free phospholipid reverse micellar media (Table 4). The optimum ranges of $\mathrm{R}$ and reaction temperature by $R$. javanicus lipase were considerably higher than those by $C$. rugosa lipase. The optimum $\mathrm{R}$ for milk fat hydrolysis by $R$. javanicus lipase by single-variable was about 18 ; whereas the same observed by multi-variable study was $14-16$.

\section{Gas chromatography of milk fat hydrolysates}

Milk fat is characterized by a broad range of fatty acids and a substantial proportion of short-chain fatty acids. Reaction products include glycerol, FFA of different chain lengths and types, and MAG and DAG of different acyl carbon number $(\mathrm{ACN})$ and regio-isomers.

The GC column separated FFA with 4-18, MAG with 10-18 and DAG with 16-36 ACN (Fig. 3). For each class of products, components with the same ACN, but different level of unsaturation, were not separated. The $s n-2 \mathrm{MAG}$ were separated from $s n-1(3)$ MAG and $s n-1,3$ DAG were separated from $s n-1,2(2,3)$ DAG. Also, impurities originating from the decomposition of the silylating reagent interfered with the $\mathrm{C} 4$ FFA. The separation efficiency observed in this study was in general agreement with that reported for the components in enzymatically interesterified milk fat using a similar column (Kalo et al., 1989).

\section{Effect of conditions on composition of hydrolysates}

Three reaction parameters - temperature, $\mathrm{pH}$, and $\mathrm{R}$ - had effects on composition of milk fat hydrolysates prepared by $R$. javanicus lipase. Those prepared under combinations of reaction conditions contained 0.1 to $0.5 \%$ glycerol, 6.4 to $26.9 \%$ FFA, 0.6 to $5.2 \% \mathrm{MAG}, 12.7$ to $27.8 \% \mathrm{DAG}$, and 39.7 to $77.1 \%$ TAG. Linear, quadratic, and interactive effects of the parameters were compared (Table 5).

Among parameters studied, $\mathrm{pH}$ had the least influence on composition of hydrolysates. Reaction temperature and $\mathrm{R}$ had significant linear and quadratic effects on the content of all major classes of components. Only FFA and MAG were influenced by interactive effects of $\mathrm{R}$ and temperature (Fig. 4).
Temperature and $\mathrm{R}$, had a considerable effect on composition of partial acylglycerols in terms of ACN and regio-isomers (Fig. $5)$. The effect of reaction temperature on the regio-isomer contents of MAG and DAG was mixed. The concentration of sn1(3) MAG and $s n-1,3$ DAG increased with the increase in the reaction temperature. On the other hand, the concentration of $s n-2$ MAG and $s n-1,2(2,3)$ DAG decreased with increase in reaction temperatures. The observed effect of temperature on content of specific regio-isomers of MAG or DAG may be attributed to altered specificity of enzyme as a result of conformational changes. They may also be due to the increased rate of spontaneous acyl migration from the $s n-2$ position to the $s n$ $1(3)$ position at higher temperatures, or to differential temperature effects on reaction kinetics.

\section{Optimization of conditions for various end products}

The optimum reaction conditions for maximization of specific components were determined based on the GLM regression models (Table 6). There were sharp differences in conditions necessary for production of a certain group of FFA, class of partial acylglycerols and regio-isomers of partial acylglycerols. Short-chain FFA could be optimally produced when the lipase reaction was carried out at lower temperature, higher $\mathrm{pH}$, and higher $\mathrm{R}$ values. Milk fat hydrolysate with a higher proportion of MAG over DAG could be prepared at $55^{\circ} \mathrm{C}$ (reaction temperature) by conducting the reaction at higher $\mathrm{R}$ and lower $\mathrm{pH}$ values. Also, different optimum reaction condition ranges were observed for different regio-isomer contents of partial acylglycerols. For instance, $s n-1$ MAG were favored over $s n-2 \mathrm{MAG}$ as reaction end-products and would be optimally produced when the reaction was carried out at higher temperature, higher $\mathrm{R}$, and lower $\mathrm{pH}$.

\section{REFERENCES}

AOAC, 1984. Official Methods of Analysis, 14th ed. Association of Official Analytical Chemists, Washington, DC.

Axum, 1989. Axum Technical Graphics and Data Analysis. TriMetrix, Inc., Seattle, WA.

Bello, M., Thomas, D., and Legoy, M.D. 1987. Interesterification and synthesis by Candida cylindracea lipase in microemulsions. Biochem. Biophys. Res. Commun. 146: 361-367.

Box, G.E.P. and Wilson, K.B. 1951. On the experimental attainment of optimum condition. J. Royal Statistical Society. Series B 13: 1-9.

Chang, P.S. and Rhee, J.S. 1990. Characteristics of lipase-catalyzed glycerolysis of triglyceride in AOT-isooctane reversed micelles. Biocatalysis 3 : 343-355.

Chen, J.P. and Pai, H. 1991. Hydrolysis of milk fat with lipase in reversed micelles. J. Food Sci. 56: 234-237.

Design-Expert 1988. Design-Expert Experimental Design, Stat-Ease, Inc., Minneapolis, MN.

Gupte, A., Nagarajan, R., and Kilara, A. 1995. Enzyme reactions in reverse micelles. In Food Flavors: Generation, Analysis and Process Influence, G. Charalambous (Ed), p. 1-74. Elsevier Science BV, Amsterdam.

Han, D. and Rhee, J.S. 1985. Batchwise hydrolysis of olive oil by lipase in AOT-isooctane reverse micelles. Biotechnol. Lett. 7: 651-656.

AOT-isooctane reverse micelles. Biotechnol. Lett. 7: 651-656.
Han, D. and Rhee, J.S. 1986. Characteristics of lipase-catalyzed hydrolysis of olive oil in AOT-isooctane reversed micelles. Biotechnol. Bioeng. 28: $1250-1255$.

Han, D., Rhee, J.S., and Lee, S.B. 1987. Lipase reaction in AOT-isooctane reversed micelles: Effect of water on equilibria. Biotechnol. Bioeng. 30: $381-388$.

Han, D., Walde, P., and Luisi, P.L. 1990. Dependence of lipase activity on water content and enzyme concentration in reverse micelles. Biocatalysis 4: $153-161$.

Hayes, D.G. and Gulari, E. 1990. Esterification reaction of lipase in reverse micelles. Biotechnol. Bioeng. 35: 793-801.

Hirata, H., Higuchi, K., and Yamashina, T. 1990. Lipase-catalyzed transesterification in organic solvent effects of water and solvent thermal stability and some applications. J. Biotechnol. 14: 157-168.

Holmberg, K., Lassen, B., and Stark, M.B. 1989. Enzymatic glycerolysis of triglyceride in aqueous and nonaqueous microemulsions. J. Am. Oil Chem. Soc. 66: 1796-1800.

Holmberg, K. and Osterberg, E. 1987. Enzymatic transesterification of a triglyceride in microemulsions. Progr. Colloid \& Polymer Sci. 74: 98-102. Holmberg, K. and Osterberg, E. 1988. Enzymatic preparation of monoglycerides in microemulsion. J. Am. Oil Chem. Soc. 65: 1544-1548.

Kalo, P., Huotari, H., and Antila, M. 1989. Pseudomonas fluorescens lipasecatalyzed interesterification of butter fat. Fett Wiss. Technol. 91: 276-281. Kilara, A. 1985. Enzyme-modified lipid food ingredients. Process Biochem. 20: $36-45$.

Kim, T. and Chung, K. 1989. Some characteristics of palm kernel olein hydrolysis by Rhizopus arrhizus lipase in reversed micelle of AOT in isooctane and additive effects. Enzyme Microb. Technol. 11: 528-532. 


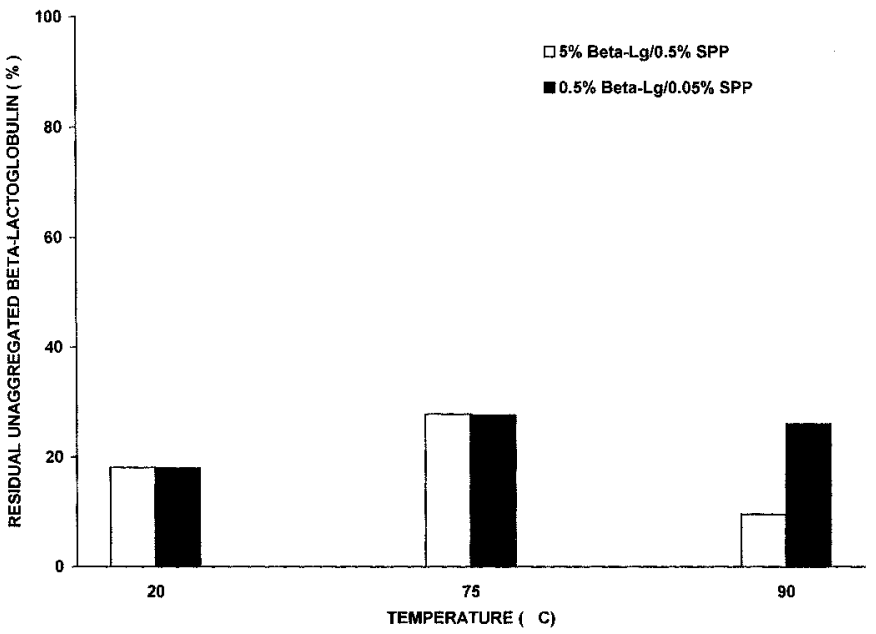

Fig. 9-Percentage unaggregated $\beta-\mathrm{Lg}$ in the filtrate of $\beta-\mathrm{Lg} / \mathrm{SPP}$ mixtures at $\mathrm{pH} 3.5$.

trostatic forces between oppositely charged gelatin and kappacarrageenan molecules resulted in precipitate formation.

Due to precipitate formation between $\beta-\mathrm{Lg}$ and SPP at $\mathrm{pH}$ 3.5 , chromatographic analysis was conducted only on the filtrate from unheated and heated $\beta-\mathrm{Lg} / \mathrm{SPP}(10: 1)$ mixtures. At $20^{\circ} \mathrm{C}$, $\approx 20 \%$ of unheated $\beta$-Lg molecules did not interact with SPP to form a precipitate (Fig. 9). After heating the $\beta$ - $\mathrm{Lg} / \mathrm{SPP}$ mixtures to $75^{\circ} \mathrm{C}$, the percentage of unaggregated $\beta-\mathrm{Lg}$ in the $\beta-\mathrm{Lg} / \mathrm{SPP}$ filtrate increased unexpectedly to $30 \%$ (Fig. 9). This increase in unaggregated $\beta-\mathrm{Lg}$ suggested that the magnitude of $\beta-\mathrm{Lg} / \mathrm{SPP}$ association forces was reduced during heating to $75^{\circ} \mathrm{C}$. No significant difference was found in percentage of unaggregated $\beta$ $\mathrm{Lg}$ in the filtrates of $0.5 \% \beta-\mathrm{Lg} / 0.05 \%$ SPP mixtures heated to 75 and $90^{\circ} \mathrm{C}$. However, the percentage of unaggregated $\beta-\mathrm{Lg}$ in the filtrate of $5 \% \beta-\mathrm{Lg} / 0.5 \%$ SPP mixtures was significantly greater at 75 than at $90^{\circ} \mathrm{C}$. This was consistent with the observation that $\beta-\mathrm{Lg}$ was more susceptible to thermal aggregation at $5 \%$ than at $0.5 \%$ in the 75 to $90^{\circ} \mathrm{C}$ temperature range.

\section{CONCLUSION}

THERMAL AGGREGATION TRANSITIONS of $\beta$ - Lg were related to $\beta-\mathrm{Lg}$ concentration and $\mathrm{pH}$. At $\mathrm{pH} 6.5$, SPP did not affect the rate of $\beta-\mathrm{Lg}$ aggregation but influenced the formation of high- molecular-weight $\beta$-Lg aggregates. At $\mathrm{pH} 3.5$, SPP interacted with $\beta-\mathrm{Lg}$ to form a cloudy white complex that precipitated on heating. Since aggregation is a prerequisite for gelation, SPP could be used to alter $\beta$-Lg aggregation and diversify the use of $\beta$ - Lg and/or whey proteins as gelling ingredients in processed foods.

\section{REFERENCES}

De Wit, J.N. 1990. Thermal stability and functionality of whey proteins. J. Dairy Sci. 73: 3602-3612.

De Wit, J.N. and Klarenbeek, G. 1989. Technological and functional aspects of milk proteins. In Milk Proteins, C.A. Barth and E. Schlimme (Ed.), p. 211-222. Steinkopff Verlag, Darmstadt, Germany.

Dickinson, E. and Stainsby, G. 1982. Colloids in Foods, p. 224-225. Applied Science Publishers Ltd., Barking, Essex, England.

Elbein, A.D. and Mitchell, M. 1975. Protein:polyanion interaction. The effect of heparin on the trehalose-phosphate synthetase of Mycobacterium smegmatis. Arch. Biochem. Biophys. 168: 369-377.

Ferry, J.D. 1948. Protein gels. Adv. Protein Chem. 4: 1-78. (Abstract). J. Dairy Sci. 76: (Suppl. 1): 112.

Harwalkar, V.R. 1980. Measurement of thermal denaturation of $\beta$-lactoglobulin at pH 2.5. J. Dairy Sci. 63: 1043-1051.

Harwalkar, V.R. 1986. Kinetic study of thermal denaturation of proteins in whey. Milchwissenschaft 41: 206-210.

Hidalgo, J. and Hansen, P.M.T. 1969. Interactions between food stabilizers and $\beta$-lactoglobulin. J. Agric. Food Chem. 17: 1089-1092.

Hollar, C.N., Parris, N., Hsieh, A., and Cockley, K.D. 1995. Factors affecting the denaturation and aggregation of whey proteins in heated whey protein concentrate mixtures. J. Dairy Sci. 78: 260-267.

Imeson, A.P., Ledward, D.A., and Mitchell, J.R. 1977. On the nature of interaction between some anionic polysaccharides and proteins. J Sci. Food teraction between som
Agric. 28: $661-668$.

Kuhn, P.R. and Foegeding, E.A. 1991. Mineral salts effects on whey protein gelation. J. Agric. Food Chem. 39: 1013-1016.

Mulvihill D.M. and Kinsella, J.E. 1987. Gelation characteristics of whey protein and $\beta$-lactoglobulin. Food Technol. 41(9): 102

Ndi, E.E., Barbosa-Canovas, G.V., and Luedecke, L.O. 1993. Rheology and microstructure of $\beta$-lactoglobulin and sodium polypectate gels. Paper No. 489, presented at 53rd Annual Meeting of the Inst. of Food Technologists, Chicago, July 10-14.

Ndi, E.E. and Brekke, C.J. 1992. Thermal aggregation properties of duck salt-soluble proteins at selected pH values. J. Food Sci. 57: 1316-1320.

SAS Institute Inc. 1985. SAS ${ }^{\odot}$ User's Guide: Basics, Version 5 Edition. SAS Institute Inc., Cary, NC.

Shimada, K. and Cheftel, J.C. 1989. Sulfhydryl group/disulfide bond interchange reactions during heat-induced gelation of whey protein isolate. J. Agric. Food Chem. 37: 161-168.

Tolstoguzov, V.B. 1986. Functional properties of protein-polysaccharide mixtures. Ch. 9. In Functional Properties of Food Macromolecules, J.R. Mitchell and D.A. Ledward (Ed.), p. 385-415. Elsevier Science Publishing Co., New York.

Watase, M. and Nishinari, K. 1983. Rheological properties of mixtures of protein-polysaccharide Dynamic viscoelasticity of blend gels of acylated gelatin, kappa-carrageenan, and agarose. Biorheology 20: 495-505.

Xiong, Y.L. and Blanchard, S.P. 1993. Viscoelastic properties of myofibrillar protein-polysaccharide composite gels. J. Food Sci. 58: 164-167.

protein-polysaccharide composite gels. J. Food Sci. 58: 164-167.
Xiong, Y.L., Dawson, K.A., and Wan, L. 1993. Thermal aggregation of $\beta-$ lactoglobulin: Effect of $\mathrm{pH}$, ionic environment and thiol reagent. J. Dairy Sci. 76: 70-77.

Ms received 2/27/95; revised 7/15/95; accepted 7/27/95.

\section{HYDROLYSIS OF MILKFAT BY LIPASE. . From page 38}

Klibanov, A.M. 1986. Enzymes that work in organic solvents. Chemtech 16: 354-359.

Lowry, R.R. and Tinsley, I.J. 1976. Rapid colorimetric determination of free fatty acids. J. Am. Oil Chem. Soc. 53: 470-472.

Minitab. 1990. Minitab Reference Manual. Minitab, Inc., State College, PA.

Nagao, A. and Kito, M. 1990. Lipase-catalyzed synthesis of fatty acid esters useful in the food industry. Biocatalysis 3: 295-305.

Osterberg, E., Blomstrom, A.C., and Holmberg, K. 1989. Lipase-catalyzed transesterification of unsaturated lipids in a microemulsion. J. Am. Oil Chem. Soc. 66: 1330-1333.

Patel, M.T. 1993. Lipase catalyzed hydrolysis of triacylglycerols in microaqueous reverse micellar systems. Ph.D. dissertation, The Pennsylvania State Univ., University Park, PA.
Patel, M.T., Nagarajan, R., and Kilara, A. 1995. Lipase-mediated hydrolysis of triacylglycerols in solvent-free reverse micellar system of lecithin in triacylglycerols. Biotechnol. Bioeng. (In press).

Schmidli, P.K. and Luisi, P.L. 1990. Lipase-catalyzed reactions in reverse micelles formed by soybean lecithin. Biocatalysis 3: 367-376.

Stark, M.B., Skagerlind, P., Holmberg, K., and Carlfors, J. 1990. Dependence of the activity of a Rhizopus lipase on microemulsion composition. Colloid Polym. Sci. 268: 384-388.

Yamane, T., Kojima, Y., Ichiryu, T., and Shimizu, S. 1988. Biocatalysis in a microaqueous organic solvent. Ann. N.Y. Acad. Sci. 542: 282-293.

Zaks, A. and Klibanov, A.M. 1988. The effect of water on enzyme action in organic media. J. Biol. Chem. 263: 8017-8021.

Ms received 2/10/95; revised 8/24/95; accepted 8/28/95. 